Michał Lipiński CM

(1) hitps://orcid.org/0000-0002-4967-3949

\title{
Duchowy klimat towarzyszący objawieniu Cudownego Medalika
}

(doi) https://doi.org/10.15633/9788374389778.01

Kiedy w 1830 roku Matka Boża objawiła się Katarzynie Labouré, ówczesna duchowość była ukształtowana przede wszystkim przez trzy wcześniejsze okresy:

- XVIII wiek, stanowiący okres rozkwitu życia kościelnego i prądów duchowości, który był równocześnie czasem przenikania idei oświeceniowych z Anglii do Francji, co osłabiało życie chrześcijańskie;

- lata 1789-1799, czyli okres rewolucji francuskiej, stanowiący trudny czas prześladowań, a nawet męczeństwa osób wierzących;

- początek XIX wieku, nazywany czasem restauracji, czyli odnowienia państwa francuskiego, a także życia kościelnego.

Nie należy się dziwić powiązaniu czynników kształtujących duchowość z historią, ponieważ praktykowanie wiary, przeżywanie relacji z Bogiem i rozwój prądów duchowości dokonuje się w konkretnych okolicznościach czasu, miejsca i środowiska. Duchowość chrześcijańska jest zakorzeniona w doczesności, odnosi się do zjawisk społecznych, politycznych, kulturowych czy ekonomicznych, kształtujących rzeczywistość, w której realizuje się dążenie do świętości. Są nawet wydarzenia, które wywierają wpływ przez dłuższy czas, czego przykładem jest rewolucja francuska albo jansenizm: ich oddziaływanie na duchowość pozostało widoczne nie tylko w XIX, ale także w XX wieku ${ }^{1}$.

1 M. Chmielewski, Wielka księga duchowości katolickiej. Audycje o życiu duchowym w Radiu Maryja i TV Trwam „Duc in altum”: odcinki 1-570 (2.01.2003-26.12.2013), Kraków 2015, s. 657. 


\section{Duchowość europejska w XVIII wieku}

XVIII wiek stanowił w Europie zachodniej epokę przejściową, nacechowaną niepokojami politycznymi i walką pomiędzy domami królewskimi ${ }^{2}$, ale był także czasem męczenników, poświęcających swe życie na misjach i podczas rewolucji francuskiej ${ }^{3}$.

W XVIII wieku Kościół sam w sobie nie stanowił władzy politycznej, był natomiast rzeczywistą władzą moralną, do której lud czuł się przywiązany, podobnie jak do jego tradycji i hierarchii. Równocześnie Kościół tamtych czasów był bardzo ściśle powiązany z władzą świecką. Ponadto rzeczywistość życia Kościoła w XVIII-wiecznej Europie naznaczona było tracącą swą skuteczność kontrreformacją. Działało wówczas wielu katolickich naukowców, a ważnym aspektem, który dostrzegano, były potrzeby ludu, czego wyraz stanowiło zaangażowanie w pomoc chorym i potrzebującym. Poza tym życie duchowe znamionował często jansenistyczny rygoryzm, wskutek którego religia bywała redukowana do moralizmu ${ }^{5}$. Taka postawa obronna była w dużej mierze reakcją na rozprzestrzeniający się na Zachodzie humanizm i tendencje wręcz poganizujące. Nadto oświecenie cechowało metodyczne wątpienie, krytyka oraz działania encyklopedystów ${ }^{6}$.

XVIII-wieczni papieże byli ludźmi gorliwymi, pobożnymi, praktykującymi umartwienia, lecz nie byli osobowościami znaczącymi na płaszczyźnie międzynarodowej, które byłyby w stanie rywalizować z oświeceniowymi władcami. Jednak papieże, pozostając wierni nauczaniu Soboru Trydenckiego, próbowali odpowiadać na ówczesne prądy myślowe. Przytoczmy kilka przykładów. Innocenty XIII w 1714 roku założył ligę wobec zagrożenia ze strony Turków i zwalczał jansenizm, czego wyrazem była wydana w 1713 roku bulla Unigenitus. Popierał także zakładanie seminariów zakonnych, przygotowujących misjonarzy do pracy ewangelizacyjnej w różnych zakątkach świata. Benedykt XIII (1724-1730) do dziewięciu godzin dziennie spę-

2 C. Brovetto, L. Mezzadri, F. Ferrario, P. Ricca, Duchowość chrześcijańska czasów nowożytnych, Kraków 2005, s. 195-196.

3 Tamże, s. 208.

4 S.-A. Leterrier, La notion du pouvoir spirituel au début du XIXe siècle, „Revue d'histoire moderne et contemporaine" 35 (1), s. 108-109.

5 C. Brovetto [i in.], Duchowość chrześcijańska czasów nowożytnych, dz. cyt., s. 199.

6 Tamże, s. 196-197. 
dzał na modlitwie, nie zaniedbując przy tym obowiązków takich, jak np. konsekracja kościołów. Klemens XII (1730-1740) wobec działalności masonerii, która przyciągała ludzi filantropią, równością i deizmem, w 1738 roku zabronił katolikom przynależności do lóż wolnomularskich. Benedykt XIV (1740-1758) zwracał uwagę na rolę inteligencji katolickiej, a szczególnie na konieczność jej wykształcenia i formacji, by dorównywała ona pod tym względem przeciwnikom Kościoła. Zwracał uwagę, że nie wystarczy potępianie błędów, lecz konieczne jest głoszenie czystej nauki, w co sam się zaangażował, pisząc encykliki doktrynalne. Zapoczątkował też reformę brewiarza, zatwierdził tłumaczenia Biblii na różne języki, zmodyfikował procedurę umieszczania ksiąg na indeksie, doceniał rolę ignacjańskich ćwiczeń duchowych i zachęcał do rozpowszechniania modlitwy medytacyjnej. Klemens XIII (1758-1769) w 1759 roku potępił Encyklopedię, a w roku 1763 pisma J.-J. Rousseau. Natomiast w 1767 roku kanonizował św. Józefa Kalasantego, wspierając tym samym ludowe szkoły katolickie?.

W XVIII wieku poszczególne państwa próbowały podporządkowywać sobie Kościół, ograniczając jego prawa. W związku z takimi praktykami papież Pius VI (1775-1799) w 1782 roku udał się do Wiednia, by przekonać Józefa II do zaniechania takich działań, ale jego misja nie zakończyła się powodzeniem ${ }^{8}$. Również Kościół francuski pozostawał nadmiernie związany z monarchią. Od czasów konkordatu bolońskiego (1516) to król mianował wszystkich biskupów i opatów ${ }^{9}$. W tej sytuacji Kościół powszechnie wykorzystywano do celów politycznych. Biskupi bardziej byli książętami, niż pasterzami, a niższe duchowieństwo było uzależnione od władców w sposób pośredni - poprzez zależność od biskupów ${ }^{10}$. Ponadto XVIII-wieczni biskupi francuscy, intelektualiści i ludzie szlachetni pozostawali zbyt słabi, by powstrzymać tendencje propagowane przez reprezentantów ówczesnej filozofii. Wspierali rozwój kultury, bibliotek, kolegiów, instytucji zakonnych i pomoc charytatywną i w duchu Soboru Trydenckiego rezydowali w diecezjach oraz troszczyli się o seminaria. Biskupami zostawali zwykle młodsi synowie rodzin arystokratycznych, którzy nie mieli szans na dziedzicze-

\footnotetext{
7 Tamże, s. 203-209, 306.

8 Tamże, s. 209-210.

9 B. Kumor, Historia Kościoła VI. Czasy nowożytne. Kościół w okresie absolutyzmu i oświecenia, Lublin 2003, s. 183.

10 M. Chmielewski, Wielka księga duchowości katolickiej, dz. cyt., s. 669-67o.
} 
nie majątku. Podejmowali oni starania o uzyskanie większej autonomii od władz świeckich, ale nie troszczyli się o pielęgnowanie więzi z papiestwem, co sprzyjało rozwojowi gallikanizmu. Nie brakowało jednak świętych biskupów, spośród których należy wymienić Ludwika de La Motte († 1774) - kaznodzieję, teologa i przeciwnika jansenizmu. Realizował on trydencki ideał kapłana i biskupa, naśladował życie trapistów, a jego duchowość ukształtowały dzieła św. Franciszka Salezego. Kierował misjami ludowymi w diecezji, pomagał chorym na cholerę i ubogim. Podkreślał rolę obowiązków stanu i konieczność częstej Komunii świętej. W swojej diecezji zaprowadził nieustanną adorację Najświętszego Sakramentu. Służył także jako kierownik duchowy osób mających znaczący wpływ na duchowość ówczesnej Francji1 ${ }^{11}$.

Wielu spośród księży (było ich wielu, według niektórych nawet zbyt wielu) doświadczało biedy, w której żył lud, co potwierdzają dokumenty z wizytacji pasterskich. Niskie wykształcenie stawało się przyczyną nadużyć w sprawowaniu sakramentów, częste były także zaniedbania obowiązków, a księża nie potrafili głosić kazań i spowiadać. Powołanie traktowano jako stan pozwalający przeżyć bez większego wysiłku, a dochód stanowiły skromne ofiary składane za pełnione posługi. Niestety ludzie świeccy w minimalnym stopniu angażowali się w życie Kościoła ${ }^{12}$.

Na nowożytność ogromny wpływ wywierało oświecenie, które jako prąd myślowy akcentowało rolę wiedzy przy równoczesnym degradowaniu autorytetu i tradycji. Około 1730 roku z Anglii dotarły do Francji nurty, takie jak deizm oraz zachwyt wolnością religijną i wolnością prasy. Teorie te zostały rozwinięte przez Monteskiusza († 1755), J.-J. Rousseau (1712-1778), Voltaire’a († 1778) i choć w pewnym sensie stanowiły zagrożenie dla Kościoła, to przyczyniły się do przezwyciężania trwających w nim zabobonów oraz do przemyślenia na nowo nauki o ludzkiej godności i wolności w oparciu o Ewangelię. Obok szkód, wynikających z myśli oświeceniowych, zaistniała okazja do oczyszczenia się Kościoła, do zrewidowania spojrzenia na Pismo święte i uznania, że nie jest ono podręcznikiem przyrodniczym, lecz przekazuje prawdę o Bogu Stworzycielu. Sytuacja ta miała także wpływ na rozwój nauki o prawach człowieka i wolności religijnej. Propagowany przez oświecenie racjonalizm i liberalizm przyczyniały się do pomniej-

11 C. Brovetto [i in.], Duchowość chrześcijańska czasów nowożytnych, dz. cyt., s. 210-212; B. Kumor, Historia Kościoła, dz. cyt., s. 62-63.

12 C. Brovetto [i in.], Duchowość chrześcijańska czasów nowożytnych, dz. cyt., s. 215. 
szania znaczenia Objawienia i autorytetu, co prowadziło do teologicznych badań, mających uzasadnić tezę, że Objawienie nie jest sprzeczne z rozumem. Jednocześnie zwracano uwagę na istnienie tajemnic wiary, które zawsze pozostaną tajemnicami, jak np. wcielenie czy odkupienie. Znalazło to wyraz w odrodzeniu myśli św. Tomasza pod postacią neoscholastyki. Jednak wśród teologów zaczął zaznaczać się rozłam pomiędzy zwolennikami neoscholastyki i modernizmu ${ }^{13}$.

XVIII wiek był czasem duchowych sporów, ale i przepowiadania słowa Bożego w formie misji ludowych, którymi zajmowały się zakony żebracze, a także powstałe w XVII wieku liczne zgromadzenia, mające to działanie w swym charyzmacie (np. misjonarze, eudyści) lub specjalnie przygotowani do tego zadania kapłani diecezjalni. Głównym zagadnieniem poruszanym w XVIII-wiecznym kaznodziejstwie byłą walka z niemoralnością i sceptycyzmem religijnym. Towarzyszyło temu odwoływanie się do tradycyjnej pobożności, która niekiedy przybierała formy graniczące z przesądem. W przepowiadaniu słowa Bożego bardzo łatwo było zostać uznanym za jansenistę albo oskarżonym o współodpowiedzialność za stan niemoralności. W kaznodziejstwie często denuncjowano błędy i posługiwano się inwektywami wobec przeciwników. Religię uważano za coś statycznego i zamkniętego, bardziej za swego rodzaju zbiór idei, w które należało wierzyć, niż za źródło żywotności i inwencji, w konsekwencji czego chrześcijaństwo jakby zamknęło się w twierdzy. Jansenizm groził zdominowaniem duszpasterstwa nie tylko w dziedzinie kaznodziejstwa, ale wpływał także na ograniczenie praktykowania życia sakramentalnego, czego wyrazem była trudność w przekonaniu wiernych do wartości częstej (to znaczy wówczas cotygodniowej) Komunii świętej jako środka do stawania się lepszym człowiekiem i unikania grzechu ${ }^{14}$.

Jansenizm nie wyeliminował jednak w klasztorach klauzurowych i wśród osób świeckich elementów mistyki. Jej ośrodkami były wspólnoty kapucynek, klarysek, tercjarek, karmelitanek czy dominikanek. Trudność, którą napotykała ówczesna mistyka, wynikała raczej z trendów kwietystycznych, krytykowanych przez kręgi jansenistyczne oraz kręgi związane

13 F. Beran, A lelki élet teológiája, Budapest 2016, s. 59-62; B. Kumor, Historia Kościoła, dz. cyt., s. $62-63$.

14 C. Brovetto [i in.], Duchowość chrześcijańska czasów nowożytnych, dz. cyt., s. 218-223, 304306, 318-319. 
z nurtami oświeceniowymi. Próbom ich pogodzenia było wydane w 1774 roku przez Euzebiusza z Amort dzieło De revelationibus, visionibus et apparitionibus privatis regulae tutae (Wszystkie zasady o objawieniach, wizjach i objawieniach prywatnych), w którym podawał on kryteria oceny zjawisk mistycznych ${ }^{15}$.

Przykładem kapłana diecezjalnego, poświęcającego się misjom ludowym, był działający w Bretanii św. Ludwik Maria Grignion de Montfort (1673-1716), któremu największą sławę przyniósł Traktat o prawdziwym nabożeństwie do Najświętszej Maryi Panny. Podejmując głoszenie misji ludowych, koncentrował się on na odnowieniu przyrzeczeń chrzcielnych, czyli na pogłębieniu przymierza z Bogiem, a osobiście podejmował wiele praktyk pokutnych. W 1702 roku założył Stowarzyszenie Córek Mądrości, zatwierdzone w 1715 roku (instytut męski w chwili jego śmierci był jeszcze w zarodku). Ponadto w 1708 roku założył dla osób świeckich Stowarzyszenie Przyjaciół Krzyża, w którego duchowości podkreślano konieczność naśladowania Chrystusa aż po krzyż $\dot{1}^{16}$.

W XVIII-wiecznej duchowości obok misji ludowych na uwagę zasługuje propagowanie ćwiczeń duchownych, możliwe dzięki zakładaniu domów rekolekcyjnych, spośród których większość pierwotnie była przeznaczona dla mężczyzn. W Bretanii w rekolekcjach brało udział nawet po sto i więcej osób, często jednak poprzestawano na ich pierwszym tygodniu, mającym prowadzić do głębokiego nawrócenia. Organizowano też ćwiczenia dla kapłanów oraz dla zakonnic i młodzieży żeńskiej ${ }^{17}$.

Nie brakowało również zaangażowania na polu działalności charytatywnej. W Chartres powstały siostry szpitalne św. Pawła (zatwierdzone w 1708 roku), siostry z St. Pons (1728), siostry szpitalne św. Augustyna (założone w Marsylii w 1727 roku) i nowe gałęzie sióstr miłosierdzia. Działalność ta cieszyła się szacunkiem nawet ze strony przeciwników Kościoła, czego wyrazem był m.in. fakt, że żaden z instytutów zajmujących się posługą w szpitalach nie został zgłoszony w czasach rewolucji francuskiej jako klasztor przeznaczony do likwidacji ${ }^{18}$.

15 M. Chmielewski, Wielka księga duchowości katolickiej, dz. cyt., s. 618, 620, C. Brovetto [i in.], Duchowość chrześcijańska czasów nowożytnych, dz. cyt., s. 254-255.

17 Tamże, s. 317, 320.

18 Tamże, s. 331-332. 
XVII i XVIII wiek były także czasem rozwoju wspólnot poświęcających się prowadzeniu działalności edukacyjnej. Wiązało się to przede wszystkim z działalnością św. Jana de la Salle (1651-1719), który założył Zgromadzenie Braci Szkół Chrześcijańskich, powszechnie nazywane braćmi szkolnymi ${ }^{19}$.

W XVIII wieku rozwijały się też różne formy pobożności, wśród których należy wyróżnić pobożność maryjną, realizowaną przez: nowenny, posty, szkaplerze, nawiedzenia sanktuariów, stowarzyszenia i konfraternie oraz dzieła miłosierdzia. W 1726 roku jezuita A. Dionisi nadał ostateczny kształt nabożeństwom majowym i akcentował rolę łączenia modlitwy z praktykowaniem cnót. Rozwijał się również kult Niepokalanego Poczęcia, czego wyrazem było składanie „ślubu krwi”, pisanego niekiedy własną krwią, co stanowiło szczególne zobowiązanie do obrony tego przywileju Matki Bożej. Charakterystyczną formą pobożności była również modlitwa w intencji dusz czyśćcowych i praktyka przygotowania do dobrej śmierci poprzez medytowanie o sprawach ostatecznych ${ }^{20}$.

W XVIII wieku wydawano Pismo święte i liczne dzieła poświęcone życiu duchowemu, m.in. św. Teresy z Ávila, św. Jana od Krzyża, św. Franciszka Salezego, Ludwika z Grenady, Jana z Ávila, Anieli z Foligno czy Katarzyny ze Sieny ${ }^{21}$.

\section{Duchowość podczas rewolucji francuskiej}

Do rewolucji francuskiej doprowadziły konflikty społeczne, które trwały zwłaszcza w Paryżu i dużych miastach w latach 1789-1794, a według niektórych historyków aż do 1815 roku, czyli do klęski Napoleona Bonapartego, choć nie brakuje i naukowców, którzy uważają, że rewolucja trwa do dzisiaj. Za jej początek uważa się zdobycie Bastylii 14 lipca 1789 roku. Była to twierdza pełniąca rolę więzienia, w którym osadzonych było wówczas zaledwie ośmiu więźniów. Według jednej z opinii impulsem do wybuchu rewolucji miał być rok 1788, w którym burze i grad wpłynęły na wysokie ceny zboża i wina, co przyczyniło się do głodu i nędzy w niektórych re-

\footnotetext{
19 Tamże, s. 326.

20 Tamże, s. 324-326.

21 Tamże, s. 323-324.
} 
gionach. Ponadto katastrofę ekonomiczną powiększył upadek niektórych manufaktur. Do tego chłopi i mieszczanie obciążeni zostali podatkami, by pokrywać koszty wojen ${ }^{22}$.

Jeśli chodzi o sytuację kościelną, w przedrewolucyjnej Francji wraz z Korsyką istniały 144 archidiecezje i diecezje, w których mieszkało 6o tysięcy księży diecezjalnych i 17 tysięcy zakonników (według innych danych liczba ta sięgała 120 tysięcy). Ludność liczyła około 22 milionów, a więc na jednego duchownego przypadało około 185 osób. Kościół francuski cieszył się czterema przywilejami: honorowym (pierwszeństwo przed innymi), kultowym (tylko kult katolicki miał prawa publiczne), sądowym i podatkowym $^{23}$.

Na gruncie życia religijnego rewolucję poprzedziły przywileje udzielane protestantom - przede wszystkim edykt tolerancyjny Ludwika XVI z 1787 roku, zezwalający im na sprawowanie kultu, ale jedynie w budynkach sa$\mathrm{kralnych}^{24}$. Już w czasie rewolucji doszło do zagarnięcia dóbr kościelnych przez państwo, co odbyło się nie bez akceptacji części pasterzy Kościoła. 26 września 1789 roku abp Paryża A.-L. Leclerc de Juigné zaproponował oddanie precjozów kościelnych niezwiązanych bezpośrednio z kultem do skarbu państwa ${ }^{25}$. Następnie 13 lutego 1790 roku Zgromadzenie Narodowe Konstytucyjne zlikwidowało wszystkie zakony z wyjątkiem tych, które zajmowały się działalnością charytatywną i prowadzeniem szkół. Unieważnione zostały także śluby zakonne, które uznano za niezgodne z prawami człowieka. Zakonnicy mogli przejść do życia świeckiego i otrzymać państwową pensję albo dożywotnio udać się do zbiorowego klasztoru. Księża zostali zobowiązani do lojalności wobec tego prawa, a odmowa wiązała się z uniemożliwieniem im pełnienia posługi ${ }^{26}$. Kościoły zaczęto zamieniać na „świątynie rozumu”, które stały się miejscem nowego kultu - w rzeczywistości ateistycznego. Taki los spotkał też paryską katedrę Notre-Dame. Organizowano bluźniercze procesje i nagminnie demolowa-

22 M. Chmielewski, Wielka księga duchowości katolickiej, dz. cyt., 657-658, 661, B. Kumor, Historia Kościoła, dz. cyt., s. 184.

23 B. Kumor, Historia Kościoła, dz. cyt., s. 183; M. Chmielewski, Wielka księga duchowości katolickiej, dz. cyt., 661.

24 B. Kumor, Historia Kościoła, dz. cyt., s. 183.

25 Tamże, s. 185.

26 M. Chmielewski, Wielka księga duchowości katolickiej, dz. cyt., s. 661; B. Kumor, Historia Kościoła, dz. cyt., s. 185. 
no wnętrza kościołów, a od biskupów i księży domagano się wyrzeczenia wiary i godności sakralnej ${ }^{27}$.

Religia zaproponowana przez rewolucjonistów nie przyjęła się na wsiach, co wpłynęło na duchowość XIX i XX wieku. Lud nie pozostał bierny, czego wyrazem stało się krwawo stłumione powstanie w Wandei ${ }^{28}$. Jednak nie brakowało wierzących, którzy byli coraz mniej związani z Kościołem, a coraz bardziej z lożami masońskimi. Ponadto w kwietniu 1790 roku powiększono zakres tolerancji religijnej, postanawiając, że nikt nie może być niepokojony z powodu swych przekonań religijnych. Jednocześnie 12 kwietnia tegoż roku odrzucono wniosek o uznanie katolicyzmu za religię państwową. Kolejne dekrety zobowiązywały kler do składania przysięgi na konstytucję cywilną, którą 20 grudnia 1790 roku podpisał król Ludwik xVI. Prawie jedna trzecia duchowieństwa i siedmiu biskupów złożyło żądaną przysięgę. Ustawa ta przyczyniła się do powstania wśród francuskich katolików dwóch obozów: prawowiernego (wiernego Rzymowi) i schizmatyckiego (uznającego konstytucję), a z czasem zaczęto przymuszać opornych duchownych do przyłączenia się do schizmy. 29 listopada 1791 roku wydano dekret, uznający za podejrzanych księży odmawiających przysięgi na konstytucję i karano ich deportacją lub zakazami publicznego sprawowania liturgii. Konstytucja wprowadzała wybory biskupów diecezji i proboszczów parafii przez uprawnionych do tego obywateli. Zatwierdzenie wyboru proboszcza należało do biskupa, wyboru biskupa zaś do metropolity. Konstytucja zakazywała natomiast wysyłania próśb do papieża o zatwierdzenie biskupów. W ten sposób zburzony został hierarchiczny ustrój Kościoła ${ }^{29}$.

Kolejnym krokiem było zlikwidowanie 10 sierpnia 1792 roku we Francji wszystkich zakonów - także tych, które dotąd wciąż mogły działać ${ }^{30}$. Decyzję tę poprzedziły ataki na życie zakonne, których narzędziem była literatura opisująca próżniactwo, chciwość i niemoralność zakonników, zaniedbania w modlitwie chórowej (negatywnych przykładów nie brakowało, gdyż często zakonnicy wybierali ten stan na mocy decyzji rodziny, a nie kierując się powołaniem). Nieco lepsza sytuacja panowała we wspólnotach

27 B. Kumor, Historia Kościoła, dz. cyt., s. 189-19o.

28 M. Chmielewski, Wielka księga duchowości katolickiej, dz. cyt., s. 661-662.

29 B. Kumor, Historia Kościoła, dz. cyt., s. 185-187.

30 Tamże, s. 188. 
żeńskich, działających na polu charytatywnym, edukacyjnym i kulturalnym $^{31}$.

Następowały dalsze ograniczenia dotyczące życia i działalności Kościoła. 26 sierpnia 1792 roku wyszło rozporządzenie o deportacji katolickich księży do Gujany w Ameryce Południowej. Mordowano lub wypędzano dostojników kościelnych, a siostry grabiono i mordowano ${ }^{32}$. 23 lipca 1793 roku księżom zagrożono karą śmierci za niepodporządkowanie się przepisom proklamującym wolność obywatelską i religijną ${ }^{33}$. Był to wyraz antyklerykalizmu wynikającego z dawnego reżimu społecznego, którego cechą było państwo religijne ${ }^{34}$. Zabroniono noszenia stroju duchownego i zakazano procesji religijnych w Paryżu oraz zmieniono rotę państwowej przysięgi. W duchu świeckim przeprowadzano różne reformy. I tak 22 września 1793 roku zniesiono chrześcijański kalendarz, a zastąpiono go kalendarzem rewolucyjnym. Niedzielę zastąpiono dniem odpoczynku co dziesięć dni (tzw. dekady, które stały się podstawą całej rachuby czasu: dzień składał się z dziesięciu godzin mających po sto minut, a te miały po sto sekund), chrześcijańskie święta zastąpiono świętami I Republiki, a miesiącom nadano nowe nazwy. Kalendarz rewolucyjny obowiązywał do $1805 \mathrm{roku}^{35}$.

Czas ten wydał wielu męczenników ${ }^{36}$, także w Rodzinie Wincentyńskiej: wśród misjonarzy i sióstr miłosierdzia. Były wśród nich szarytki, które poniosły śmierć męczeńską w Arras: bł. Maria Magdalena Fontaine (1723-1794), bł. Maria Teresa Lanel (1745-1794), bł. Teresa Magdalena Fantou (1747-1794), bł. Joanna Gérard (1752-1794). 18 czerwca 1793 roku po zdobyciu przez powstańczą armię Angers, planowano również udanie się na Paryż, ale uniemożliwili to chłopi, którzy powrócili do domów na żniwa. Wielu mieszkańców Wandei zostało wymordowanych ${ }^{37}$. Od 15 września 1793 roku po odmówieniu złożenia przysięgi siostry przebywały w areszcie. Stracone zostały 26 czerwca 1794 roku $^{38}$. Męczenniczki Zgro-

31 Tamże, s. 184.

32 M. Chmielewski, Wielka księga duchowości katolickiej, dz. cyt., s. 661.

33 B. Kumor, Historia Kościoła, dz. cyt., s. 188.

34 S.-A. Letterrier, La notion du pouvoir spirituel au début du XIXe siècle, dz. cyt., s. 109.

35 B. Kumor, Historia Kościoła, dz. cyt., s. 188; M. Chmielewski, Wielka księga duchowości katolickiej, dz. cyt., s. 658.

36 B. Kumor, Historia Kościoła, dz. cyt., s. 187.

37 M. Chmielewski, Wielka księga duchowości katolickiej, dz. cyt., s. 662.

38 A. Vernaschi, Dziedzictwo. Święci i błogosławieni rodziny wincentyńskiej, Kraków 20oo, s. 9195. 
madzenia Sióstr Miłosierdzia w Angers: bł. Maria Anna Vaillot (1734-1794) i bł. Otylia Baumgarten (1750-1794) - posługiwały w tamtejszym szpitalu. 19 stycznia 1794 roku zostały aresztowane, a wyrok wykonano 1 lutego ${ }^{39}$. Męczennicy ze Zgromadzenia Księży Misjonarzy: bł. Piotr Renat Rogue (1758-1796), bł. Ludwik Józef François (1751-1792), bł. Jan Henryk Gruyer (1734-1792), bł. Mikołaj Colin (1730-1792) i bł. Jan Karol Caron (1730-1792) - ponieśli śmierć męczeńską 3 września 1792 roku w paryskim Seminarium św. Firmina ${ }^{40}$. Ale i w tym czasie sprawdziły się słowa Tertuliana o krwi męczenników jako nasieniu chrześcijan ${ }^{41}$.

Stanowisko Piusa VI wobec rewolucji francuskiej było nieco spóźnione potępił ją dopiero 10 marca 1791 roku. Wówczas w brewe Quod aliquantum cywilną konstytucję uznał za nieważną i nieobowiązującą, co powtórzył w skierowanym do całego duchowieństwa i wiernych we Francji brewe Caritas z 13 kwietnia tegoż roku. Równocześnie papież zawiesił w czynnościach sakralnych duchownych, którzy złożyli przysięgę na konstytucję i wyznaczył termin czterdziestu dni na odwołanie przysięgi. Wybory proboszczów i biskupów uznał za nieważne ${ }^{42}$. Jednakże, wciągnięty w gry polityczne, w 1797 roku musiał podpisać traktat w Tolentino, na mocy którego przyłączył się do koalicji antyfrancuskiej, a 1798 roku został usunięty z Watykanu i internowany ${ }^{43}$.

28 lipca 1794 roku rządy Robespierre’a obalono, a on sam następnego dnia został ścięty. Kościoły zostały otwarte, a niezaprzysiężeni księża zaczęli spełniać funkcje sakralne. Jednak nie oznaczało to swobody. Dekret z 30 maja 1795 roku zwrócił katolikom świątynie pod warunkiem, że księża złożą przysięgę posłuszeństwa wobec praw republiki, czego większość księży odmówiła. Kolejny dekret z 5 września 1797 roku zobowiązywał księży do przysięgi na nienawiść do monarchii, a także ponowił dekrety o deportacji. W takich okolicznościach przywrócono służbę Bożą w około czterdziestu tysięcy świątyń. Jednak po dziesięciu latach rewolucji i administracyjnego zeświecczenia życie religijne zostało ogromnie osłabione, a organizacja kościelna całkowicie zniszczona. Liczne stolice biskupie

39 Tamże, s. 84-9o.

40 Tamże, s. 70-83.

41 M. Chmielewski, Wielka księga duchowości katolickiej, dz. cyt., s. 669.

42 B. Kumor, Historia Kościoła, dz. cyt., s. 186.

43 C. Brovetto [i in.], Duchowość chrześcijańska czasów nowożytnych, dz. cyt., s. 209-210. 
były nieobsadzone lub miały schizmatycki episkopat wierny konstytucji. W parafiach brakowało jedności wiernych z duchowieństwem, a posługa duszpasterska była niedostateczna. Nie brakowało jednak gorliwych misjonarzy świeckich i duchownych, troszczących się o życie duchowe wiernych ${ }^{44}$. Choć był to okres sekularyzacji, wystąpień przeciw klerowi i laicyzacji struktur kościelnych, to równocześnie był to czas odnowienia papiestwa, które zyskało swobodę działania. Jest to też czas ekspansji działalności misyjnej Kościoła. Dobrodziejstwem płynącym z ruchów rewolucyjnych dla Kościoła było jego oczyszczenie ${ }^{45}$.

\section{Próby odnowy życia kościelnego po rewolucji francuskiej}

Lata 1799-1815 nazywane są okresem napoleońskim. Napoleon w 1799 roku powrócił z Egiptu i dokonał zamachu stanu, obalając dyrektoriat i kończąc rewolucję francuską. Kres jego władzy związany jest z klęską w $1814 \mathrm{roku}^{46}$.

10 listopada 1799 roku we Francji, po obaleniu rządów dyrektoriatu, na czele rządu postawiono trzech konsulów pod kierownictwem Napoleona Bonaparte. Celem uregulowania relacji między państwem i Kościołem 15 lipca 1801 roku podpisano konkordat, który obowiązywał do roku 1905, a służył jako wzór dla konkordatów z innymi państwami przez cały XIX $w_{i e k^{47}}$, a przynajmniej do jego połowy ${ }^{48}$. Konkordat był dziełem kompromisu i nie przywracał Kościołowi takiego znaczenia, jakie miał przed rewolucją. Był raczej narzędziem w rękach polityków, szukających za wszelką cenę poparcia ze strony Kościoła, niż probą docenienia jego roli. Wyrazem tego było choćby to, że 5 czerwca 1800 roku w przemówieniu do duchowieństwa mediolańskiego Napoleon ukazywał religię jako podporę państwa i zapewniał, że dołoży wszelkich starań, by Francję pojednać ze Stoli-

44 B. Kumor, Historia Kościoła, dz. cyt., s. 189-191.

45 C. Brovetto [i in.], Duchowość chrześcijańska czasów nowożytnych, dz. cyt., s. 13-15.

46 B. Kumor, Historia Kościoła, dz. cyt., s. 178.

47 Tamże, s. 191-192.

48 Tamże, s. 179. 
cą Apostolską. Bonaparte opowiadał się bowiem za wszechwładzą państwa w stosunku do Kościoła i dążył do wykorzystania duchownych, nie wyłączając papieża, do celów politycznych. W myśl konkordatu religia katolicka, będąca religią większości obywateli francuskich, otrzymała gwarancję praktykowania w sposób wolny i publiczny z zachowaniem przepisów policyjnych. Dążąc do utwierdzenia swej władzy, Napoleon w 1802 roku przeprowadził swój wybór na dożywotniego konsula, a 18 maja 1804 roku decyzją senatu proklamowano we Francji dziedziczne cesarstwo w rodzinie Napoleona. Na uroczystości koronacyjne, które odbyły się 4 grudnia 1804 roku w Paryżu, cesarz Francuzów zaprosił papieża Piusa VII, który zgodził się na wyjazd do Paryża w nadziei na uregulowanie relacji między Kościołem a państwem francuskim ${ }^{49}$, w którym ołtarz i tron były silnie powiązane $^{50}$. Jedynym osiągnięciem papieża podczas pobytu w Paryżu była zgoda cesarza na przywrócenie niektórych zgromadzeń zakonnych: misjonarzy, Zgromadzenia Ducha Świętego i szarytek, wznowienie seminarium dla misji zagranicznych i zniesienie kalendarza republikańskiego ${ }^{51}$.

Okres po upadku Napoleona, po kongresie wiedeńskim (1815), był wolny od działań wojennych i nazwano go okresem restauracji ${ }^{52}$. Towarzyszył mu wzrost liczby powołań kapłańskich i reorganizacja życia parafialnego, powstanie zakonów i zgromadzeń oraz apostolskich dzieł zrzeszających. Był to też czas rozwoju służby charytatywnej ${ }^{53}$.

Duchowość początków XIX wieku naznaczona była nadal wpływami jansenizmu oraz racjonalizmu - echami idei oświeceniowych i romantyzmu ${ }^{54}$, będącego przeciwwagą dla oświecenia, co przejawiło się także w odrodzeniu religijnym i licznych nawróceniach. Cechami romantyzmu były: irracjonalizm, otwarcie na nadprzyrodzoność, mistycyzm (kontakt ze światem pozaziemskim, duchami, aniołami i demonami poprzez wizje, sny, odczucia, które mają miejsce często na miejscach odludnych, ciemnych), mroczność i tajemniczość, nawiązanie do ludowych opowiadań,

49 Tamże, s. 191-195.

50 Tamże, s. 184. Jednak nie brakowało duchownych wybijających się na polu nauki i cnoty. Por. C. Brovetto [i in.], Duchowość chrześcijańska czasów współczesnych, dz. cyt., s. 19.

51 B. Kumor, Historia Kościoła, dz. cyt., s. 195.

52 B. Kumor, Historia Kościoła, dz. cyt., s. 178; M. Chmielewski, Wielka księga duchowości katolickiej, dz. cyt., s. 676.

53 C. Brovetto [i in.], Duchowość chrześcijańska czasów współczesnych, dz. cyt., s. 25-26.

54 Tamże, s. 15. 
baśni, folkloru, gwary i obyczajów, centralny motyw kobiety ze względu na jej zdolność do intuicyjnego patrzenia na świat nadprzyrodzony i ponadzmysłowy, uczuciowość, indywidualizm (osamotnieni, wyobcowani bohaterowie), profetyzm (umiejętność jasnowidzenia, przewidywania przyszłości), konieczność walki z tyranią, zniewoleniem, uprzedzeniami, mesjanizm (poczucie epokowej misji do spełnienia). Dlatego romantyzm przyciągał ludzi o mentalności rewolucyjnej, zmierzającej do zapewnienia wolności narodom, ale i inicjującej przebudzenie religijne. Na jego powstanie wpłynęły też idee rewolucji francuskiej. Cechuje się on własną wizją świata, która mówi o istnieniu tego, co materialne, poznawane przy pomocy zmysłów, i tego, co niewidzialne, duchowe, poznawane przy pomocy wiary, intuicji i uczuć. Romantyzm zaakcentował istnienie człowieka wewnętrznego, uduchowionego. Trwał on w Europie Zachodniej od końca XVIII wieku do lat czterdziestych XIX wieku. Można w nim wyróżnić trzy fazy:

- romantyzm wczesny (1798-1804) - czasy rewolucji francuskiej,

- rozkwit (1804-1815) - czasy napoleońskie,

- późny romantyzm (od 1815 roku) - od kongresu wiedeńskiego ${ }^{55}$.

Wyrazem odnowy romantycznej w Kościele były liczne nawrócenia ${ }^{56}$. Cechami charakterystycznymi pobożności romantycznej były: kult Eucharystii - akcentujący adorację (Eucharystia rozumiana jako pamiątka i kontynuacja męki Pańskiej), kult Najświętszego Serca Pana Jezusa, kult Najdroższej Krwi Chrystusa, pobożność maryjna - stanowiąca reakcję na jej zwalczanie w czasie rewolucji francuskiej, kult świętych ${ }^{57}$ oraz bogactwo przeżyć mistycznych ${ }^{58}$. Jednak nie był to nurt bez wad. Choć na gruncie niemieckim pozwalał pokojowo współistnieć katolicyzmowi i protestantyzmowi, problemem było to, że stawiał on religię i praktyki katolickie na równi z innymi religiami, np. pochodzącymi z Indii czy Egiptu ${ }^{59}$.

XIX wiek to również czas troski o formację duchowieństwa, czego wyrazem było zakładanie nowych seminariów, w których panowała dyscyplina stanowiąca skuteczny środek w formacji kleru. Wielu kapłanów z tego

55 M. Chmielewski, Wielka księga duchowości katolickiej, dz. cyt., s. 680-681; C. Brovetto [i in.], Duchowość chrześcijańska czasów współczesnych, Kraków 2005, s. 24.

56 C. Brovetto [i in.], Duchowość chrześcijańska czasów wspótczesnych, dz. cyt., s. 24.

57 M. Chmielewski, Wielka księga duchowości katolickiej, dz. cyt., s. 690.

58 C. Brovetto [i in.], Duchowość chrześcijańska czasów wspótczesnych, dz. cyt., s. 23.

59 J. Aumann, Zarys historii duchowości, Kielce 1993, s. 298-299. 
czasu zostało wyniesionych na ołtarze. Było to owocem troski o formację duchowieństwa, wypracowywanie stylu życia kapłańskiego na wzór seminarium św. Sulpicjusza w XVII wieku ${ }^{60}$. Jeśli chodzi o kapłanów tego okresu wyniesionych do chwały ołtarzy nie sposób nie wspomnieć św. Jana Marii Vianney’a (1786-1859), który był synem biednych chłopów, dorastającym w czasach rewolucji francuskiej. Posługując w Ars-en-Dombes, żył ideałami życia kapłańskiego, które streścił w Myślach. Akcentował rolę osobistego przykładu, uczciwego życia, świętego, spokojnego i pełnego miłosierdzia. Świadomy był odpowiedzialności za dusze, które prowadzi, co szczególnie dokonywało się przy okazji posługi w konfesjonale ${ }^{61}$.

Choć konkordat nic nie mówił na temat życia zakonnego, to nastąpiło jego odrodzenie. Spośród wspólnot żeńskich zezwolono szarytkom na działalność w szpitalach i szkolnictwie, sercankom (1800) na wychowywanie i nauczanie dziewcząt. W latach 1804-1810 na terenie Francji powstało kilka nowych zgromadzeń zakonnych do opieki nad chorymi i kształcenia młodzieży. Około 1810 roku w granicach wielkiego Cesarstwa Francji było 2057 klasztorów i 16447 zakonnic, zajętych pielęgnowaniem chorych i nauczaniem w szkołach ${ }^{62}$. Rozwój życia zakonnego w XIX wieku dotyczył również odnowienia wspólnot monastycznych po rewolucji francuskiej, podczas której mnisi zmuszani byli do życia jako duchowieństwo diecezjalne. Towarzyszyło temu poparcie wiernych świeckich, którzy pragnęli powrotu zakonników do zdewastowanych po rewolucji klasztorów, co zaowocowało wieloma przykładami gorliwych zakonników. Wzrastała wśród nich również świadomość konieczności podjęcia zadań społecznych bez zaniedbania klasycznej ascezy, umartwienia i intensywnego życia modlitewnego. Następowała też odnowa trzecich zakonów ${ }^{63}$.

Zakony żebracze powoli przezwyciężały kryzys. Z trudem odradzali się karmelici, augustianie, eremici i dominikanie. Odnowa tych ostatnich stała się możliwa w dużej mierze dzięki Henrykowi Lacordaire’owi (1802-1861). W początkach XIX wieku rozwijały się nowe formy życia konsekrowanego - pojawiły się wspólnoty kapłańskie poświęcające się życiu

60 C. Brovetto [i in.], Duchowość chrześcijańska czasów współczesnych, dz. cyt., s. 29, 33; M. Chmielewski, Wielka księga duchowości katolickiej, dz. cyt., s. 670.

61 C. Brovetto [i in.], Duchowość chrześcijańska czasów współczesnych, dz. cyt., s. 34-36.

62 B. Kumor, Historia Kościoła, dz. cyt., s. 195.

63 C. Brovetto [i in.], Duchowość chrześcijańska czasów współczesnych, dz. cyt., s. 46-48. 
apostolskiemu, głoszeniu słowa Bożego, promowaniu pobożności ludowej i kultu eucharystycznego ${ }^{64}$. XIX wiek to czas powstawania wielu zgromadzeń kapłańskich: oblatów Maryi Niepokalanej założonych przez Brunona Lanteriego (1759-1830) w 1816 roku, Instytutu Synów Maryi Niepokalanej, wywodzącego się od Józefa Frassinettiego, oblatów św. Alfonsa założonych przez św. Antoniego Marię Gianellego (1789-1845) ${ }^{65}$. Powstawało wiele zgromadzeń żeńskich, które podejmowały pracę wśród ubogich, chorych, sierot, wśród opuszczonej młodzieży, dziewcząt pracujących w fabrykach, szkołach i parafiach, a także w oświacie. Wśród nich należy wspomnieć: córki miłości bł. Magdaleny z Canossy (1774-1835) czy siostry miłosierdzia św. Joanny Antydy Thouret $(1765-1825)^{66}$. We Francji w Chartres Maria Poussepin († 1744) założyła siostry miłosierdzia dominikanki od ofiarowania - tercjarki pracujące w małych osadach. Św. Joanna Delanoue († 1736) w Saumur dała początek zgromadzeniu sióstr św. Anny od Opatrzności Bożej, które posługiwało w sierocińcu i hospicjum dla starców ${ }^{67}$. Zakony borykały się jednak z wieloma trudnościami, czego przykładem jest sytuacja panująca u sióstr miłosierdzia. Św. Katarzyna Labouré, kiedy przybyła w gronie 112 nowicjuszek do Paryża do domu przy ul. du Bac, przyjęła strój siostry miłosierdzia. Choć św. Wincenty pragnął, aby wszystkie szarytki nosiły jednakowy strój prostych kobiet, w domu macierzystym siostry nosiły stroje wykonane $z$ różnych rodzajów tkanin i różnego koloru. Nie brakowało nawet sióstr noszących habity wykonane z borsuczej lub owczej wełny. Niektóre zaś posiadały elementy stroju właściwego damom: trzewiki, pończochy, przesadnie duże kornety, dekoracje stroju w postaci kołnierzy, zakładek, wstążek. Przejawiało się w tym rozluźnienie, które próbowano przezwyciężyć w okresie restauracji ${ }^{68}$.

XIX wiek cechowała także pobożność maryjna, która zwalczana była przez rewolucję francuską, czego wyrazem była profanacja katedry Notre-Dame w Paryżu, gdzie figurę Maryi zastąpiono figurą bogini Rozumu. Ale w 1801 roku konkordat pozwalał już na cztery święta maryjne, wśród których znajdowało się Wniebowzięcie. Rozwinęły się też sanktua-

64 Tamże, s. 46-47, 49.

65 Tamże, s. 33-34.

66 Tamże, s. 49.

67 Tamże, s. 329-330.

68 R. Laurentin, Powiernica Niepokalanej. Życie i misja świętej Katarzyny Labouré (1806-1876), Warszawa 1990, s. 32. 
ria maryjne. Punktem granicznym były objawienia św. Katarzynie Labouré w 1830 roku $^{69}$. Poza tym w XIX wieku rozwijało się wiele instytutów o tytule maryjnym. We Francji założono: oblatów Maryi Niepokalanej w 1816 roku przez Eugeniusza de Mazenoda, Zgromadzenie Małych Braci Maryi - w 1817 roku, Stowarzyszenie Maryi - w 1822 roku przez G. C. Colina, Zgromadzenie Braci Naszej Pani Miłosierdzia - w 1839 roku przez G. B. C. Sheppersa, augustynianów od Wniebowzięcia - w 1845 roku w Nimes ${ }^{70}$. Kolejnym rysem, cechującym życie kościelne w pierwszej połowie XIX wieku, był ultramontanizm (od łac. ultra montes - „ponad górami”). Jego główną myślą było podporządkowanie spraw Kościołów lokalnych decyzjom papieża i w ten sposób przywrócenie mu najwyższej zwierzchności także w dziedzinie polityczno-społecznej. Ultramontanizm akcentował strukturę widzialną Kościoła, co prowadziło do manifestowania wiary na zewnątrz. Centralna rola papiestwa powodowała, że pobożność stawała się eklezjocentryczna i to stanowiło gwarancję kroczenia bezpieczną drogą. W dobrym tonie $\mathrm{w}$ salonach było szczycenie się posiadaniem kierownika duchowego obdarzanego dużym autorytetem - niekiedy aż po ślub bezwzględnego posłuszeństwa wobec niego. W życiu miejscowych wspólnot ultramontanizm prowadził do akcentowania roli proboszcza, gromadzącego wspólnotę parafialną i będącego znakiem jedności z Kościołem powszechnym. Często prowadziło to do aktywności wyłącznie duchownych i bierności wiernych świeckich. Towarzyszyła temu wzajemna nieufność ${ }^{71}$. We Francji zwolennikiem ultramontanizmu był F.-R. de Lamennais ${ }^{72}$. Wraz z ultramontanizmem rozwijała się też neoscholastyka, głównie dzięki rzymskim jezuitom. Do jej popularności w Kościele przyczyniła się encyklika Leona XIII Aeterni Patris z 4 sierpnia 1879 roku. Centrum neoscholastyki stanowiła szkoła w Tybindze, dzięki której, w duchu scjentyzmu, możliwe stawało się uznanie teologii za naukę na wzór nauk ścisłych ${ }^{73}$.

Przeciwwagą dla nurtów przyznających większą rolę papiestwu był eudajmonizm, który miał zmierzać do zjednoczenia chrześcijan poprzez po-

69 C. Brovetto [i in.], Duchowość chrześcijańska czasów współczesnych, dz. cyt., s. 64.

70 Tamże, s. 65.

71 M. Chmielewski, Wielka księga duchowości katolickiej, dz. cyt., s. 673-674.

72 C. Brovetto [i in.], Duchowość chrześcijańska czasów współczesnych, dz. cyt., s. 18.

73 M. Chmielewski, Wielka księga duchowości katolickiej, dz. cyt., s. 675. 
dejmowanie inicjatyw międzywyznaniowych ponad dogmatami. Chciano stworzyć „święte przymierze”, konfederację wyznań. Miejsce tych zabiegów zaczęły zajmować działania zmierzające do powrotu na łono katolicyzmu chrześcijan odłączonych ${ }^{74}$.

W większości krajów parafia odgrywała decydującą rolę w odnowie duchowości, choć wśród szlachty i mieszczaństwa nadal rozpowszechniony był model kapłana jako domowego nauczyciela. Parafia stanowiła wówczas centrum opieki społecznej, nauczania, formacji katechetycznej i społecznej, centrum życia sakramentalnego, miejsce codziennego praktykowania wiary. Chociaż bywały negatywne przykłady duszpasterzy ospałych, troszczących się o dobro własne i swojej rodziny, to było też bardzo wielu proboszczów pragnących spełniać swoje obowiązki pomimo tego, że żyli w miejscach odosobnionych i prowadzili życie ubogie ${ }^{75}$.

Biblia nie była powszechnie czytana ani podczas sprawowania liturgii, ani w nabożeństwach paraliturgicznych. Akcentowano raczej zewnętrzny kult Najświętszego Sakramentu. Rola Eucharystii w pobożności znalazła wyraz w nazwie wspólnot. Podjęto również procesje i pielgrzymki do sanktuariów związanych z cudami eucharystycznymi. Pobożność eucharystyczna akcentowała adorację i zadośćuczynienie. Duchowość ta w XIX wieku miała być adoracją, serdeczną i ufną rozmową, do czego zachęcał św. Jan Maria Vianney ${ }^{76}$. W związku z kultem eucharystycznym rozwijał się kult Najdroższej Krwi Pańskiej ${ }^{77}$.

Istotny był również kult Najświętszego Serca Pana Jezusa. We Francji wiązał się on z publikacją w 1815 roku książeczki pt. Zbawienie Francji, w której zawarto zachętę do poświęcenia się Sercu Jezusa. Szerzenie tego kultu wymagało zmagań z jansenistami, uważającymi go za niezgodny z czystością i prostotą wiary. Szczególnym miejscem kultu Najświętszego Serca Pana Jezusa było opactwo w Des Oiseaux. W końcu w 1833 roku bp de Quélen pozwolił na obchodzenie miesiąca Serca Pana Jezusa w tym opactwie, a w 1856 roku ustanowione zostało święto Najświętszego Serca Pana Jezusa ${ }^{78}$.

74 C. Brovetto [i in.], Duchowość chrześcijańska czasów wspótczesnych, dz. cyt., s. 18-19.

75 Tamże, s. 32-33.

76 Tamże, s. 55-57.

77 Tamże, s. 61.

78 Tamże, s. 61-63. 


\section{Podsumowanie}

Jak widać, początek XIX wieku we Francji z punktu widzenia życia duchowego był okresem naznaczonym wieloma trudnościami. Nosił na sobie piętno trendów panujących w ciągu minionych czterystu lat, wśród których należy wymienić: odrodzenie, reformację, oświecenie i rewolucję francuską ${ }^{79}$. Zauważalna była wówczas aktywność laikatu, co było odpowiedzią na sekularyzację życia społecznego i antyklerykalizm. Wynikało to z niechęci do hierarchicznego Kościoła, co doświadczane jest aż po czasy współczesne. Wiele ruchów rewolucyjno-postępowych, sprzeciwiających się feudalizmowi, dało podstawę do pojawienia się romantyzmu, wyrażającego się w filozofii, kulturze, sztuce, obyczajach i duchowości. Była to wyraźna odpowiedź na racjonalizm ${ }^{80}$.

W 1830 roku, roku objawień, które stały się udziałem św. Katarzyny Labouré, rewolucja lipcowa obaliła we Francji króla Karola X, brata Ludwika XVIII, i oddała rządy wybrańcowi mieszczaństwa, Ludwikowi Filipowi z orleańskiej linii Burbonów. Ostateczny cios ideom oświecenia zadał romantyzm, a przede wszystkim odrodzony katolicyzm, który po 1830 roku rozpoczął skuteczną walkę o wyzwolenie Kościoła ze zniewolenia ze strony państwa ${ }^{81}$.

Ponadto w pierwszej połowie XIX wieku można w dziedzinie duchowości zauważyć wiele negatywnych nurtów, jak indywidualizm i subiektywizm, sceptycyzm i relatywizm, a także idee parlamentaryzmu i nacjonalizmu ${ }^{82}$, które miały swe źródło w oświeceniu ${ }^{83}$. W XIX wieku odżyło oświecenie w postaci liberalizmu jako pragnienia wolności. Polityka cechowała się akcentowaniem wolności religijnej, parlamentaryzmu, uwolnieniem gospodarki i nurtami wolnościowymi w niektórych państwach. Liberalizm dał odczuć swą obecność także w Kościele i panował wśród inteligencji katolickiej, podkreślającej rozdział Kościoła od państwa. Wiązano z tym nadzieje na przyciągnięcie do Kościoła ludzi młodych, czego przedstawi-

79 B. Kumor, Historia Kościoła, dz. cyt., s. 177.

80 M. Chmielewski, Wielka księga duchowości katolickiej, dz. cyt., s. 669; C. Brovetto [i in.], Duchowość chrześcijańska czasów wspótczesnych, dz. cyt., s. 16-17.

81 B. Kumor, Historia Kościoła, dz. cyt., s. 177-178.

82 Tamże, s. 177.

83 Tamże, s. 183. 
cielem na gruncie francuskim był Lacordaire. Tendencje te przybrały jednak skrajne formy, jak np. modernizm ${ }^{84}$.

\section{Abstrakt}

Duchowy klimat towarzyszacy objawieniu Cudownego Medalika

Duchowy klimat czasów, w których miało miejsce objawienie Cudownego Medalika św. Katarzynie Labouré, ukształtował się dzięki zetknięciu się różnych prądów począwszy od XVIII wieku. Był to czas rozkwitu życia kościelnego, choć czasów tych nie należy idealizować. Obok wysiłków zmierzających do poprawy formacji duchowieństwa i wielu inicjatyw w dziedzinie działalności edukacyjnej i charytatywnej, Kościół mierzył się z błędnymi prądami - zwłaszcza jansenizmem. Ponadto okres ten przyniósł idee oświeceniowe, które znalazły swój wyraz w rewolucji francuskiej. Czas ten był bardzo trudny dla Kościoła, ponieważ stał się czasem prześladowań i wielu męczenników. Wydarzenia te dotknęły również Rodzinę Wincentyńską, do której należą siostry miłosierdzia - zgromadzenia żeńskiego, do którego należała św. Katarzyna Labouré. Objawienia, które przeżyła w paryskiej kaplicy domu macierzystego sióstr miłosierdzia, miały miejsce w czasie restauracji, czyli odnowy życia kościelnego po rewolucji francuskiej, który jednak był też okresem prób instrumentalnego wykorzystania Kościoła przez władzę polityczną. Był to też czas naznaczony romantyzmem, który cechował się zwróceniem się ku wierze i praktykom religijnym.

Słowa kluczowe: życie duchowe we Francji, życie duchowe w Europie, prześladowanie Kościoła podczas rewolucji francuskiej, okres restauracji

\section{Abstract}

Spiritual climate accompanying the revelation of the Miraculous Medal

84 F. Beran, A lelki élet teológiája, dz. cyt., s. 62-63. 
The spiritual climate of the time in which the Miraculous Medal was revealed to St. Catherine Labouré was shaped by the meeting of various currents, beginning in the 18th century. Alongside efforts to improve the formation of the clergy and many initiatives in education and charity, the Church struggled with erroneous currents - especially Jansenism. In addition, this period brought Enlightenment ideas that found expression in the French Revolution. This time was very difficult for the Church, as it became a time of persecution and many martyrs. These events also affected the Vincentian Family, which includes the Daughters of Charity, the women's congregation to which St. Catherine Labouré belonged. The time of the revelations that she experienced in the Paris chapel of the Motherhouse of the Daughters of Charity took place at the time of the Restoration, that is, the renewal of Church life after the French Revolution, which, however, was also a period of attempts by political power to instrumentalize the Church. It was also a time marked by Romanticism, which boasted a turn to faith and religious practices.

Keywords: spiritual life in France, spiritual life in Europe, persecution of the Church during the French Revolution, restoration period

\section{Bibliografia}

1. Aumann J., Zarys historii duchowości, Kielce 1993.

2. Beran F., A lelki élet teológiája, Budapest 2016.

3. Brovetto C., Mezzadri L., Ferrario F., Ricca P., Duchowość chrześcijańska czasów nowożytnych, Kraków 2005.

4. Brovetto C., Borriello L., Della Croce G., Secondin B., Duchowość chrześcijańska czasów współczesnych, Kraków 2005.

5. Chmielewski M., Wielka księga duchowości katolickiej: Audycje o życiu duchowym w Radio Maryja i TV Trwam „Duc in altum!": odcinki 1-570 (2 I 2003-26 XII 2013), Kraków 2015.

6. Kumor B., Historia Kościoła VI: Czasy nowożytne. Kościół w okresie absolutyzmu i oświecenia, Lublin 2003.

7. Laurentin R., Powiernica Niepokalanej: Życie i misja świętej Katarzyny Labouré (1806-1876), Warszawa 1990. 
8. Leterrier S.-A., La notion du pouvoir spirituel au début du XIXe siècle, „Revue d'histoire moderne et contemporaine”, N 1, 35 (1988), s. 107122.

9. Vernaschi A., Dziedzictwo: Święci i błogosławieni rodziny wincentyńskiej, Kraków 2008. 